\title{
Food-Based Dietary Guidelines - Practical Aspects of Implementation
}

16th International ISFE Symposium, Vienna, June 28, 2006

When we look back about 60 years, nutrient deficiencies were a major problem in Europe. Towards the end of the last century, deficiencies were much less frequent, but the upcoming abundance of food resulted in an increase in cardiovascular disease and stroke. At the present time, too many people all over the world are eating too much and are physically inactive. As a result, obesity is increasing dramatically and is now recognized as one of the most serious problems in the industrialized as well as developing world. In both cases, neither nutrition nor lifestyle was and is appropriate. Actually, it is now well established what we should eat to stay healthy, but people do not listen or do not believe in the sometimes contradictory recommendations that are issued by various organizations and by the media. Therefore, the responsible scientific organizations and the governments have to improve their communication on how and what to eat. In 1996, FAO/ WHO published that the dietary recommendations have to be practical, to be comprehensible, and to be culturally acceptable. The key concept for communication needs to be reconsidered. If possible, such food-based guidelines should be visualized in a simple way. In this symposium, some of these questions are addressed. Which types of concepts and ways of communication have been developed? Models of balanced diets have been proposed and visualized such as the Nutrition Circle, Food Pyramid or in the form of campaigns like '5-a-day'. The goal of this symposium is to look at the practical aspects of implementation and communication of these nutritional messages.

This symposium was organized by The International Foundation for the Promotion of Nutrition Research and Nutrition Education (ISFE) which is supported by AMC International Alfa Metalcraft Corporation AG, a company that develops and sells high-quality products for gentle cooking without added water and fat. The organizers thank AMC for supporting this symposium.

Paul Walter, Basel Ibrahim Elmadfa, Vienna

\begin{tabular}{ll}
\hline KARGER & ( 2007 S. Karger AG, Basel \\
0250-6807/07/0518-0001\$23.50/0 \\
$\begin{array}{l}\text { Fax +4161306 1234 } \\
\text { E-Mail karger@karger.ch } \\
\text { www.karger.com }\end{array}$ & $\begin{array}{l}\text { Accessible online at: } \\
\text { www.karger.com/anm }\end{array}$
\end{tabular}

